\title{
KUALITAS GEL PENGHARUM RUANGAN BERBAHAN DASAR KARAGENAN DAN TEPUNG SAGU DENGAN PEWANGI JERUK PURUT
}

\author{
Raja Bonan Dolok Sormin ${ }^{\star}$, Adrianus O.W. Kaya, Jemris Maahury \\ Fakultas Perikanan dan Ilmu Kelautan, Universitas Pattimura \\ Jalan Mr.Chr.Soplanit. Kampus Poka, Ambon \\ Diterima: 8 September 2020/Disetujui: 5 Maret 2021 \\ ^Korespondensi: sormindolok@gmail.com
}

Cara sitasi: Sormin RBD, Kaya AOW, Maahury J. 2021. Kualitas gel pengharum ruangan berbahan dasar karagenan dan tepung sagu dengan pewangi jeruk purut. Jurnal Pengolahan Hasil Perikanan Indonesia. 24(1): 20-26.

\begin{abstract}
Abstrak
Setiap orang memerlukan suasana ruangan yang nyaman untuk melakukan aktivitas. Untuk tujuan tersebut, maka digunakan pengharum ruangan. Pengharum ruangan yang baik untuk kesehatan adalah pengharum ruangan dengan bahan-bahan alami. Dewasa ini telah banyak dikembangkan gel pengharum ruangan, karena bahan ini praktis, tidak mudah tumpah, dapat dibuat dalam berbagai bentuk dan lebih tahan lama. Penelitian ini bertujuan untuk membuat gel pengharum ruangan dengan kombinasi karagenan dan pati sagu sebagai bahan pembentuk gel dan menggunakan pewangi minyak jeruk purut. Perbandingan tepung karagenan dan tepung sagu yang digunakan adalah 3:1 dengan konsentrasi minyak jeruk purut 0,5\%; $1 \%$, dan 1,5\%. Hasil pengamatan memperlihatkan bahwa pengharum ruangan dengan kombinasi karagenan dan pati sagu sebagai bahan pembentuk gel dan minyak jeruk purut sebagai pewangi dengan konsentrasi $1,5 \%$, dan $1 \%$ menghasilkan nilai sineresis yang sama atau yang terkecil dan selanjutnya konsentrasi $1,5 \%$ memiliki total penguapan zat cair yang rendah, bobot gel (berat gel sisa) besar, retensi besar dan release yang rendah, dibandingkan dengan perlakuan yang lainnya. Dengan demikian konsentrasi 1,5\% menjadi konsentrasi terbaik yang digunakan.
\end{abstract}

Kata kunci: karagenan, minyak jeruk purut, pati sagu, pengharum ruangan

\section{Quality of Gel Fragrance Made of Carrageenan and Sago Flour Scented by} Kaffir Lime

\begin{abstract}
Everyone needs a comfortable room atmosphere for carrying out activities. For this purpose, air freshener is used. An air freshener that is good for health is an air freshener with natural ingredients. Currently, air freshener in the form of gel is being manufactured for some reasons such as not easily spilled, the fragrance is longer binding, easy to use, elastic, and the design easily created. This study aimed to make the gel air freshener with a combination of carrageenan and sago starch as a gelling agent and using kaffir lime oil as a fragrance. The ratio of carrageenan powder and sago powder was 3:1 with kaffir lime oil concentrations of $0.5 \%, 1 \%$, and $1.5 \%$. Gelling air freshener with a combination of carrageenan and sago starch as a gelling agent and kaffir lime oil as a fragrance with a concentration of $1.5 \%$, and $1 \%$ resulted in the same or the smallest synere-sis value and then a concentration of $1.5 \%$ had a lower value in total evaporation of the liquid, higher in residual gel weight and the retention as well as lower in its release compared to other treatments. Thus, a room freshener by concentration of $1.5 \%$ was the best treatment.
\end{abstract}

Keyword: air freshener, carrageenan, kaffir lime oil, sago starch 


\section{PENDAHULUAN}

Ruangan sebagai tempat untuk melakukan aktivitas memerlukan suasana yang nyaman dan menyehatkan. Upaya untuk membuat ruangan menjadi nyaman adalah dengan memanfaatkan bahan alami sebagai pengharum ruangan.. Dewasa ini telah banyak dikembangkan gel pengharum ruangan, karena bahan ini praktis, tidak mudah tumpah, dapat dibuat dalam berbagai bentuk dan lebih tahan lama. Bentuk gel membuat bahan yang mudah menguap (volatil) menjadi lebih lambat menguap (Fitrah 2013). Gel pengharum ruangan lebih disukai sebab bau wanginya lebih bertahan daripada bentuk yang lain, juga karena bahannya bersifat alami dan tidak membahayakan lingkungan (Wahyuni 2016).

Bahan pembuat gel yang biasa dimanfaatkan adalah kappa karagenan yang berasal dari rumput laut Eucheuma cottonii atau Kappahycus alvarezii. Kelemahan dari kappa karagenan adalah gelnya yang bersifat rapuh, sehingga untuk mengatasinya ke dalam bahan ini ditambahkan tipe pati yang lain seperti pati sagu. Pati sagu mengandung sekitar $27 \%$ amilosa dan $73 \%$ amilopektin pada konsentrasi yang sama pati sagu mempunyai viskositas yang tinggi disbanding serealia lainnya (Swinkels 1985). Amilosa 250-300 unit D glukosa yang berikatan $\alpha 1,4$ glikosidik merupakan rantai terbuka dan amilopektin terdiri dari 1,4 glikosidik dan sebagian 1,6 glikosidik menyebabkan terjadinya cabang.

Karagenan merupakan bahan pembentuk gel yang bersifat thermo reversible dan juga akan berubah menjadi larutan kental dimasukkan ke dalam larutan garam. Karagenan dapat digunakan sebagai bahan pengental dan penstabil (Van de Velde et al. 2002). Karagenan adalah olahan lanjutan dari alkali treated cottonii (ATC) atau semi refined carrageenan (SRC). Tingkat kemurnian SRC lebih rendah dari refined carrageenan karena kandungan sulfatnya masih tinggi, sehingga daya pembentukan gelnya rendah (Anggadiredja et al. 2010). Kegunaan karagenan dalam pembuatan pengharum ruangan adalah sebagai bahan pengemulsi minyak wangi. Karagenan dijadikan sebagai pembentuk gel dengan fungsi menahan/ memperlambat penguapan wangi atau aroma yang terdapat pada gel pengharum ruangan (Hargreaves 2003).

Pohon sagu banyak tumbuh di negara -negara tropis khususnya di Asia Tenggara seperti Indonesia dan Malaysia, sebagian Melanesia, Micronesia dan beberapa daerah di Amerika Selatan (Polnaya et al. 2009). Jumlah tanaman sagu terluas di dunia terdapat di Indonesia seluas 1.128 juta hektar, merupakan 51,3\% dari tanaman sagu dunia diikuti oleh negara Papua Nugini sebesar 43,3\%(Abner dan Miftahorrahman 2002).

Masyarakat Maluku memanfaatkan sagu sebagai salah satu bahan pokok pangan denganmengolahnya menjadi papeda yang memiliki kandungan karbohidrat yang tinggi. Komponen penyusun sagu adalah amilosa 27\% dan amilopektin 73\% (Swinkels 1985). Tingginya kadar amilopektin pada sagu menyebabkan sagu bersifat lengket sehingga tidak baik digunakan sebagai bahan pembuat keik, roti maupun mi. Pati sagu merupakan komponen yang mempunyai beberapa sifat yang mirip yaitu sebagai komponen pembentuk gel, penstabil, dan pengental.

Minyak jeruk purut digolongkan sebagai minyak atsiri yang memiliki bau khas bersifat mudah menguap pada suhu kamar (Gunawan dan Sri 2004). Minyak jeruk purut dapat digunakan sebagai penyegar udara, karena dapat menangkal partikel-partikel logam di udara sehingga kandungan oksigen udara meningkat serta menaikkan ozon. Minyak jeruk purut juga bersifat antibakteri, sehingga ketika disemprotkan ke dalam kamar udara di kamar menjadi segar (Rahmaisni 2011). Oleh karena itu pada penelitian ini dibuat gel, dengan mencampurkan tepung karagenan dan pati sagu sebagai pembentuk gel, dengan maksud untuk memperlambat penguapan minyak atsiri jeruk purut.

Penelitian ini bertujuan untuk menentukan karakteristik gel pengharum ruangan yang dibuat dari kombinasi karagenan dan sagu yang diberi pewangi minyak jeruk purut. 


\section{BAHAN DAN METODE Bahan dan Alat}

Bahan penelitian yang digunakan terdiri dari tepung karagenan, pati sagu, minyak sari nilam, minyak sari jeruk purut, propilen glikol, natrium benzoat dan akuades.

Peralatan terdiri dari: gelas ukur, gelas kimia, pipet, kompor listrik, timbangan analitik (merek OHAUS), pengaduk gelas, sudip, cetakan plastik, kertas label, plastik bening, penjepit.

\section{Metode Penelitian Prosedur kerja}

Tepung karagenan ditimbang sebanyak 5,25 g (3/4 bagian dari campuran, kemudian ditempatkan dalam wadah plastik, selanjutnya tepung pati sagu ditimbang sebanyak 1,75 $\mathrm{g}$ (1/4 bagian dari campuran tepung). Kemudian natrium benzoat ditimbang sebanyak $0,1 \mathrm{~g}$; propilen glikol diukur sebanyak $10 \mathrm{~mL}$ dan minyak jeruk purut terdiri dari 3 komposisi yaitu $0,5 \%, 1 \%$ dan $1,5 \%$ ditambah $1 \%$ minyak nilam. Selanjutnya tepung karagenan, pati sagu, natrium benzoat dicampurkan dalam wadah plastik sampai homogen. Bahan lainnya yaitu propilen glikol, minyak jeruk purut, dan minyak nilam ditempatkan dalam wadah tersendiri dan diaduk hingga homogen. Selanjutnya dipanaskan akuades sebanyak 90 mLhingga suhu mencapai $80-85{ }^{\circ} \mathrm{C}$. Setelah itu bahan-bahan yang telah dicampur sampai homogen (tepung karagenan, pati sagu, dan natrium benzoat), dimasukkan sedikit demi sedikit ke dalam akuades dengan tetap diaduk secara terus menerus hingga pati sagu, natrium benzoat, dan karagenan tidak ada yang menggumpal. Setelah semua bahan telah tercampur dengan baik, kemudian suhu diturunkan menjadi $65{ }^{\circ} \mathrm{C}$ dan selanjutnya dimasukkan propilen glikol, minyak jeruk purut dan minyak nilam yang telah tercampur dan tetap terus diaduk. Jika telah tercampur merata, kemudian gel di tuang dalam cetakan hingga gel terbentuk sempurna selama kurang lebih 2 jam dalam suhu ruangan.

\section{Analisis sampel}

Analisis sampel yang digunakan dalam peneitian ini meliputi nilai sineresis, nilai susut bobot, penguapan air, analisis retensi dan release secara kuantitatif.

\section{Nilai sineresis (AOAC 1995)}

Sineresis terjadi selama penyimpanan pada suhu ruangan selama 24 jam. Sineresis dihitung berdasarkan berat yang hilang selama penyimpanan dan kemudian dibandingkan dengan berat awal dari gel, dengan perhitungan sebagai berikut:

$\%$ sineresis $=\frac{\text { berat awal-berat akhir }}{\text { berat awal }} \times 100 \%$

\section{Nilai susut bobot (Fitrah 2013)}

Nilai susut bobot diuji dengan melakukan penimbangan berat gel seminggu sekali sebanyak 4 kali. Susut bobot dihitung dengan cara menimbang nilai penurunan berat gel setiap minggu $\left(M_{n}\right)$ dikurangi dengan nilai berat gel pada hari pertama pembuatan gel $\left(\mathrm{M}_{0}\right)$.

nilai susut bobot $=\frac{\text { bobot gel minggu ke-n }\left(M_{)}\right)(g)}{\text { bobot gel minggu ke } 0\left(M_{\mathrm{o}}\right)(\mathrm{g})} \times 100 \%$

\section{Penguapan zat cair (Fitrah 2013)}

Cara pengujian penguapan zat cair adalah dengan mengukur berat gel seminggu sekali sebanyak 4 kali, sehingga lama penyimpanan gel pengharum ruangan adalah 4 minggu. Total penguapan zat cair dapat dihitung dengan rumus:

total penguapan zat cair $=\frac{\text { total zat cair yang menguap }\left(\mathrm{M}_{-}-\mathrm{M}_{\mathrm{N}}\right)}{\text { bobot minyak+akuades }} \times 100 \%$

keterangan:

$\mathrm{M}_{\mathrm{n}}=$ berat gel pada waktu penimbangan $(\mathrm{g})$

$\mathrm{M}_{\mathrm{o}}$ = berat awal $(\mathrm{g})$ (satuan)

\section{Analisis retensi dan release secara kuantitatif (Kaya 2015)}

Analis retensi dan release dilakukan dengan cara membuat produk gel pengharum ruangan dengan berat tertentu (g), kemudian dilakukan pengamatan selama 30 hari dengan cara melakukan penimbangan peoduk gel pengharum ruangan untuk mengetahui nilai pengurangan berat tiap minggu. Pengamatan terhadap gel pengharum ruangan dibuat sebanyak 2 kali ulangan dan dilakukan secara duplo untuk semua konsentrasi pewangi serta gel tanpa minyak atsiri sebagai kontrol. Untuk mendapatkan nilai retensi dan release dari produk gel pengharum ruangan dilakukan sesuai dengan perhitungan sebagai berikut:

$\%$ release $=\frac{\text { berat awal-berat minggu ke-n }}{\text { berat awal }} \times 100 \%$

$\%$ retensi $=100 \%-\%$ release minggu ke-n 


\section{Analisis Data}

Pengamatan dilakukan dengan dua kali ulangan kemudian dirata-ratakan. Hasil rata-rata kemudian disajikan dalam bentuk histogram dan tabel.

\section{HASIL DAN PEMBAHASAN Sineresis}

Hasil penelitian menunjukkan nilai sineresis pada tiga konsentrasi perlakuan $0,5 \%, 1 \%$ dan $1,5 \%$ adalah $0,36 \% ; 0,33 \%$; dan 0,33\% berturut-turut (Figure 1).

Figure 1 menunjukkan bahwa nilai sineresis gel pengharum baik pada konsentrasi $1 \%$ maupun $1,5 \%$ adalah sama dengan nilai $0,33 \%$. Nilai tersebut merupakan nilai yang terkecil dibandingkan dengan konsentrasi pewangi $0,5 \%$ yang memiliki nilai sineresis $0,36 \%$. Penyebab terjadinya sineresis adalah berkurangnya air dari matriks gel. Sineresis dapat dikurangi dengan cara formulasi bahan penyusun hidrokoloid secara tepat pembentuk gel. Faktor-faktor yang memengaruhi sineresis adalah suhu, komposisi polisakarida penyusun, kelembapan udara, dan kandungan garam (Kaya 2015).

Sineresis merupakan penguapan air bebas yang terdapat pada permukaan suatu bahan gel pengharum ruangan selama 24 jam (Natasasmita 2011). Kuncari et al. 2014 menyatakan angka sineresis yang tinggi menunjukkan gel yang tidak stabil. Ketika gel dipanaskan hingga mencapai titik didih, maka dalam larutan akan terjadi susunan acak dari polimer kappa karagenan. Ketika dilakukan pendinginan, akan terjadi rantai heliks ganda membentuk ikatan silang secara berkelanjutan sehingga terbentuk matrik. Pada proses pendinginan seterusnya akan terbentuk agregat yang mengakibatkan terdorongnya air bebas keluar gel. Semakin tinggi nilai sineresis, permukaan gel pengharum yang dihasilkan berair dan gampang patah, dan sebaliknya jika nilai sineresis kecil maka gel pengharum ruangan semakin elastis, permukaan tidak basah dan gel lentur (Mas 2013).

Semakin banyak jumlah zona ikatan, semakin meningkat nilai sineresis, karena terbentuknya ikatan heliks dan agregat akan mempersempit rongga antara ikatan sehingga air bebas terlepas (Lee et al. 2008).

\section{Susut Bobot}

Variasi nilai susut bobot disebabkan oleh beberapa faktor antara lain komposisi pengharum, nilai sineresis, efek penggabungan antara kappa karagenan dengan pati sagu. Komponen terbesar penyusun minyak jeruk purut adalah: sitronelal, sitronelil dan sitronelol asetat. Komponen tersebut memiliki titik didih $206{ }^{\circ} \mathrm{C}$ dan memiliki berat molekul 154,249 Da. serta memiliki rantai karbon yaitu sitronelal (3,7-dimetil-6oktenal) dan sitronelol (3,7 dimetil oktenol). Hasil analisis menunjukkan bahwa pengaruh pada besarnya berat gel yang tersisa hingga akhir penyimpanan adalah disebabkan besar kecilnya konsentrasi. Semakin besar konsentrasi minyak jeruk purut yang digunakan maka berat sisa gel juga semakin besar dibandingkan dengan konsentrasi yang lain. Konsentrasi perlakuan $1,5 \%$ memiliki bobot gel yang tersisa banyak yaitu 95,33\%, oleh karena itu minyak jeruk purut yang dilepaskan ke udara sedikit.

Savary et al. (2008) dan De Roos (2000) dalam De Roos (2009), melaporkan retensi komponen wangi pada pengharum ruangan

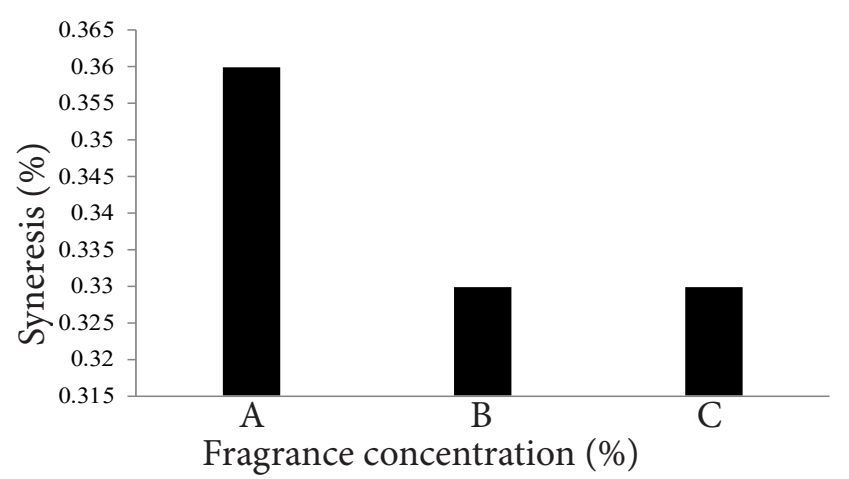

Figure 1 Syneresis value of gel fragrance; $A=0.5 \% ; B=1.0 \% ; C=1.5 \%$ 


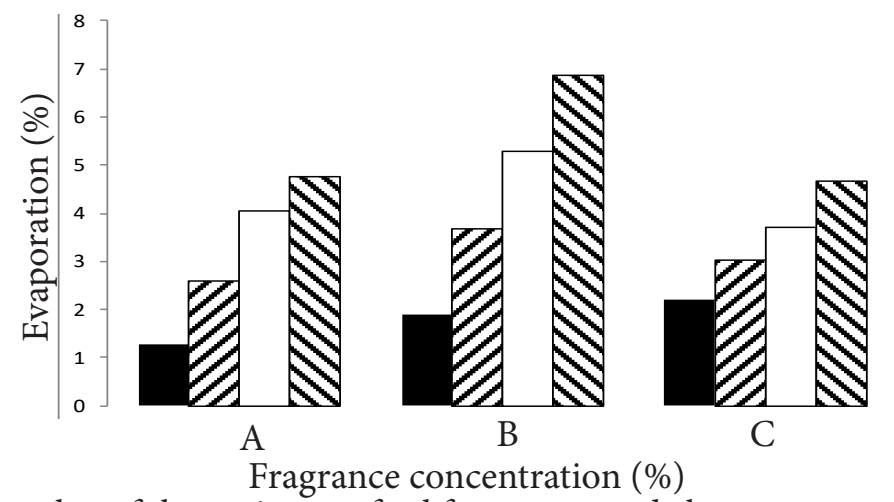

Figure 2 Evaporation value of the moisture of gel fragrance made by carrageenan; $A=0.5 \% ; B=1 \%$ $\mathrm{C}=1.5 \% ; \square$ Week 1; $\mathbb{Z}_{\text {, Week 2; }} \square \mid$ Week 3; $\mathbb{N}$ Week 4.

Table 1 Release value of kaffir lime oil of gel fragrance made by carrageenan

\begin{tabular}{|c|c|c|c|c|c|}
\hline \multirow{2}{*}{ Parameter } & \multirow{2}{*}{$\begin{array}{c}\text { Fragrance } \\
\text { concentration (\%) }\end{array}$} & \multicolumn{4}{|c|}{ Week } \\
\hline & & I & II & III & IV \\
\hline \multirow[t]{3}{*}{ Release (\%) } & 0,5 & 1.29 & 2.58 & 4.04 & 4.77 \\
\hline & 1 & 1.89 & 3.68 & 3.99 & 6.85 \\
\hline & 1,5 & 2.19 & 3.01 & 3.71 & 4.67 \\
\hline \multirow[t]{2}{*}{ Release Average } & & 1.79 & 3.09 & 3.91 & 5.43 \\
\hline & 0,5 & 98.71 & 97.42 & 95.96 & 95.23 \\
\hline Retension & 1 & 98.10 & 96.32 & 96.00 & 93.15 \\
\hline Ethanol extract & 1,5 & 97.81 & 96.99 & 96.29 & 95.33 \\
\hline Control Release (\%) & No fragrance & 1.73 & 3.22 & 4.68 & 6.12 \\
\hline
\end{tabular}

lebih disebabkan oleh terjerapnya komponen pengharum tersebut pada jaringan kompleks maupun matriks dari gel. Bila minyak jeruk purut lebih banyak terjerap pada bagian zona gel karagenan akan menyebabkan terbentuknya gel pengharum ruangan dengan nilai sineresis tinggi, sebaliknya apabila komponen minyak jeruk purut terperangkap pada bagian zona asosiasi atau percampuran antara karagenan dan pati sagu, maka akan terbentuk gel pewangi ruangan yang mempunyai nilai sineresis rendah.

\section{Retensi dan Release Gel Pengharum Ruangan}

Hasil penelitian menunjukkan berat rata-rata gel pengharum ruangan sebesar $36 \mathrm{~g}$. Rekapitulasi pengamatan release gel pengharum ruangan menggunakan minyak jeruk purut dapat dilihat pada Table 1.

Table 1 menunjukkan jumlah rataan release atau pelepasan pengharum jeruk purut gel pengharum ruangan setelah penyimpanan
4 minggu yaitu 5,43\%. Release pewangi minyak jeruk purut selama empat minggu pemakaian terjadi secara linier. Nilai release terendah terdapat pada konsentrasi pewangi minyak jeruk purut $1,5 \%$. Konsentrasi ini memiliki nilai release yang kecil yaitu 4,67\% dibandingkan dengan konsentrasi lainnya, karena pada konsentrasi ini minyak jeruk purut yang dilepaskan ke udara kecil dan retensi atau gel yang tersisa juga besar.

Naknean dan Meenune (2010) melaporkan faktor-faktor yang berpengaruh terhadap retensi dan release bahan mudah menguap meliputi sifat fisikokimia bahan dan komposisi polisakarida. Bahan aroma berantai lurus dengan berat molekul yang tinggi lebih lama terjerap matriks berbanding bahan aroma berantai pendek dengan berat molekul yang lebih rendah. Perbedaan struktur karbohidrat berpengaruh terhadap komponen aroma. Semakin tinggi konsentrasi polisakarida maka semakin rendah release komponen aroma yang disebabkan perubahan viskositas polisakarida. 


\section{KESIMPULAN}

Konsentrasi pewangi pada gel pengharum ruangan yang terbuat dari karagenan dan pati sagu sebagai bahan pembentuk gel dan minyak jeruk purut sebagai pewangi dengan konsentrasi $1,5 \%$, dan $1 \%$ menghasilkan nilai sineresis yang sama atau yang terkecil dan selanjutnya konsentrasi $1,5 \%$ memiliki total penguapan zat cair kecil, bobot gel (berat gel sisa) besar, retensi besar dan release kecil, dibandingkan dengan perlakuan yang lainnya. Konsentrasi 1,5\% menjadi konsentrasi terbaik yang digunakan.

\section{UCAPAN TERIMA KASIH}

Terima kasih disampaikan kepada Kepala Laboratorium THP, FPIK, Universitas Pattimura yang telah memfasilitasi penelitian ini.

\section{DAFTAR PUSTAKA}

Abner L, Miftahorrahman. 2002. Keragaman industri sagu Indonesia. Warta Penelitian Dan Pengembangan Tanaman Industri. 8 (1).

Anggadiredja JT, Zatnika A, Purwanto H, Istini S. 2006. Rumput Laut. Penerbit Swadaya. Jakarta.

[AOAC] Association of Official Analytical Chemist. 2005. Official Method of Analysis of the Association of Official Analytical of Chemist. Virginia (US): The Association of Analytical Chemist, Inc.

De Roos, KB. 2009. Effect of texture and microstructure on flavour retention and release. International Dairy Journal. 13 (2): 93-105

Fitrah AN. 2013. Formulasi Gel Pengharum Ruangan Menggunakan Karagenan dan Glukomanan Dengan Pewangi Minyak Jeruk Purut dan Kenaga. [Skripsi]. Bogor (ID): Institut Pertanian Bogor.

Gunawan dan Sri. 2004. Ilmu Obat Alam (Farmakologis) Jilid 1. Yogyakarta: Penebar Swadaya

Hargreaves T. (2003). Chemical formulation: An Overview of surfacant-based preparations used in everyday life. England: Royal Society of Chemistry Press.

Hidayat F. (2006). Pengaruh Kombinasi Karagenan Dan Sodium Lauryl Sulfat
Serta Penambahan Ekstrak Pemphis acidula Terhadap Karakteristik Sabun Mandi Cair. [Skripsi]. Bogor (ID): Institut Pertanian Bogor.

Kaya AOW. 2015. Perancangan Proses Pembuatan Gel Pengharum Ruangan Berbasis Campuran Semirefined Carrageenan dan Glukomanan dalam Pembuatan Gel Pengharum Ruangan. [Disertasi]. Sekolah Pascasarjana Institut Pertanian Bogor.

Kuncari ES, Iskandarsyah, Praptiwi. 2014. Evaluasi, uji stabilitas fisik dan sineresis sediaan gel yang mengandung minoksidil, apigenin dan perasan herba seledri (Apium graveolens L.). Buletin Penelitian Kesehatan. 42(4): 213-222

Mas S. 2013. Pengaruh Penambahan Minyak Nilam sebagai Fiksatif terhadap Ketahanan Wangi Gel Pengharum Ruangan Alami. [Skripsi]. Bogor: Institut Pertanian Bogor.

Naknean P, Meenune M. 2010. Factors affecting retention and release of flavour compounds in food carbohydrates. Review article. International Food Research Journal. 17: 23-34.

Natasasmita, S. 2011. Pengantar Evaluasi Daging. Fakultas Peternakan. Institut Pertanian Bogor.

Polnaya FJ, Talahatu J, Marseno DW. 2009. Karakteristik tiga jenis pati sagu (Metroxylon sp.) hidrosipropil. AGRITECH Majalah Ilmu Dan Teknologi Pertanian. 29(2): 87-95.

Rahmaisni A. 2011. Aplikasi Minyak Atsiri Pada Produk Gel Pengharum Ruangan Anti Serangga. [Skripsi]. Bogor: Institut Pertanian Bogor.

Sastrohamidjojo H. 2004. Kimia Minyak Atsiri. Yogyakarta: Gadjah Mada University Press.

Swinkels JJM. 1985. Sourch of Starch, its Chemistry and Physics. Di dalam G.M.A. Van Beynum and J. A. Roels. 1985. Starch Convention Technology. Marcel Dekker, Inc, New York.

Van de Velde F, Knutsen SH, Usov AI, Romella HS, Cerezo AS. 2002. IH and $13 \mathrm{C}$ high resolution NMR spectoscopy of carrageenans: Aplication in research 
and industry. Trend In Food Science And Technology. 13:73-92.

Wahyuni TR. 2016. Formulasi Gel Pengharum Ruangan Menggunakan Karagenan dan
Gom Xantan dengan Minyak Nilam sebagai Fiksatif dan Minyak Kenanga sebagai Pewangi [Skripsi]. Medan (ID) Universitas Sumatera Utara. 